\title{
ГЕОГРАФІЧНІ АСПЕКТИ ФОРМУВАННЯ ЗМІСТУ ПРИРОДООХОРОННИХ ЗНАНЬ УЧНІВ ОСНОВНОЇ ШКОЛИ
}

Япринець Т. С. Географічні аспекти формування змісту природоохоронних знань учнів основної школи.

У статті розкрито дидактичні особливості формування змісту природоохоронних знань у процесі навчання географії в основній школі. Узагальнено біологічні і географічні підходи до вивчення природоохоронних питань у школі. Обгрунтовано доцільність посилення географічних аспектів у змісті екологічної освіти та іï трансформацію в енвайроментальну освіту. Запропоновано структуру природоохоронних знань учнів, які вони опановують у процесі навчання географії, за елементами змісту і напрямами охорони природи.

Ключові слова: природоохоронні знання, геоекологічний підхід, методика навчання географіï.

Япринец Т. С. Географические аспекты формирования содержания природоохранных знаний учащихся основной школы.

В статье раскрыты дидактические особенности формирования содержания природоохранных знаний в процессе обучения географии в основной школе. Обобщены биологические и географические подходы к изучению природоохранных вопросов в школе. Обоснована целесообразность усиления географических аспектов в содержании экологического образования и его трансформация в енвайроментальное образование. Предложена структура природоохранных знаний учащихся, которыми они овладевают в процессе обучения географии, по элементам содержания и направлениям охраны природы.

Ключевые слова: природоохранные знания, геоэкологический подход, методика обучения географии.

Yaprynets T. S. Geographical aspects of environmental knowledge content formation of secondary school students.

The features of environmental knowledge formation in the process of Geography teaching at secondary school are shown in the article.

The biological and geographical approaches to the studying of environmental issues at school are summarized. The expediency of strengthening the geographic issues in the content of environmental education and its transformation into environmental education are proved. The structure of students' environmental knowledge which they acquire in the process of Geography learning by the content elements and the direction of nature protection is proposed.

Key words: environmental knowledge, geoecological approach, methods of Geography teaching.

На сучасному етапі взаємодії суспільства і природи, коли людство опинилося на межі екологічної катастрофи, в умовах глобальних змін клімату, деградації екосистем і ресурсних обмежень посилюється увага до екологічної освіти, яка включає формування у підростаючого покоління глибоких природоохоронних знань. У Національній доктрині розвитку освіти України у XXI столітті, Концепції екологічної освіти України та інших державних документах 
у галузі охорони довкілля акцентовано увагу на формуванні готової до природоохоронної діяльності особистості, яка має активну екологічну позицію і не допускає руйнівної поведінки в довкіллі.

Оскільки у вітчизняній школі відсутній окремий предмет з екології та раціонального природокористування, то проблема формування природоохоронних знань вирішується на міжпредметній основі, при цьому головне дидактичне навантаження в цьому питанні покладено на біологію та географію. У Державному стандарті базової і повної загальної середньої освіти 2011 року серед пріоритетів освітньої галузі «Природознавство», до якої належить географія, наголошено на формуванні природознавчої компетентності учня, яке має відбуватися шляхом засвоєння системи знань про природу, розвитку ціннісних орієнтацій у різних сферах життєдіяльності та природоохоронної практики, забезпечення єдності інтелектуального та емоційного сприйняття природи 3 практичною природоохоронною діяльністю.

В українському суспільстві екологічна освіта у процесі навчання географії традиційно знаходиться в полі уваги: науковців-географів - А. Некос, Л. Нємець, С. Сонько, О. Топчієва та ін.; педагогів і методистів - Є. Копильця, В. Корнєєва, О. Плахотник, Н. Пустовіт та ін. Посилити географічні позиції у постановці, розв'язувати та вивченні екологічних проблем прагнуть і зарубіжні фахівці - В. Жекулін, Т. Кучер, В. Максаковський, Т. Міллер, В. Ніколіна, М. Родзевич, Т. Савцова, В. Сухоруков та ін.

Метою статmі є визначити дидактичні особливості формування змісту природоохоронних знань у процесі навчання географії в основній школі.

У книзі «Географічна культура» за авторством В. Максаковського екологізація визначена як один із чотирьох наскрізних напрямків географічної науки і шкільної географії (поряд з гуманізацією, соціологізацією та економізацією). При цьому екологізацію серед них він називає головним, «диригуючим» [9, с. 333]. Розглядаючи проблеми, що стоять на шляху екологізації шкільної географії, науковець звертає увагу на навчально-методичну проблему розмежування, поділу праці між географією і геоекологією, з одного боку, і біологією та біоекологією - 3 іншого. При цьому він вказує, що звісно, з багатьох питань геоекологи i біоекологи стоять на однакових позиціях. Головне ж невдоволення географів і геоекологів викликане значною перевагою, яку має класична біоекологія над геоекологією в екологічній освіті школярів. Як приклад автор наводить російські підручники 3 інтегрального курсу «Екологія», які написані лише 3 позицій біоекології: у них є «екосистема», але немає «геосистеми», є «біоценоз», проте немає «геобіоценозу» [9, с. 335-336]. Ми погоджуємося із зауваженнями В. Максаковського i вважаємо, що сучасній вітчизняній школі також притаманна диспропорція в бік біології при формуванні природоохоронних знань школярів, яка склалася історично. Є. Копилець звертає увагу на те, що у процесі вивчення теми «Біосфера» природознавство широко оперує поняттям «екосистема», яке не співвідноситься з базовим для географії поняттям природного комплексу [5, с. 36]. На його думку, коректне використання термінології та іiі взаємна узгодженість між предметами - «суміжниками» істотно поліпшать засвоєння теми. Під час дослідження наступності у формуванні природоохоронних понять у курсі загальної географії 6-го класу після шкільного курсу природознавства (5 клас) ми зауважили, що в нових програмах зберігається суттєва вада екосистемний підхід до формування системи природоохоронних знань. Зокрема, при вивченні розділу 3. «Земля - планета сонячної системи» в змісті навчального матеріалу вона розглядається як середовище існування живих організмів (Тема 2) і вводиться поняття «екосистема», а серед вимог учні повинні називати склад екосистеми і наводити приклади 
природних і штучних екосистем. Натомість у курсі «Загальної географії», до якого переходить провідна роль у формуванні природоохоронних знань у 6-му класі, домінуючим $\epsilon$ геосистемний (ландшафтний) підхід, за вимогами програми учні повинні наводити приклади природних комплексів та комплексів, змінених людиною (Тема 5. » Природні комплекси»). Фактично маємо різні погляди біолога (екосистема) і географа (природний комплекс) на одні й ті самі ділянки місцевості - ліс, озеро, поле, сад.

У середовищі науковців охорону природи розглядають і як самостійну галузь знань, що відокремилась від екології, і як прикладний напрямок екологічної науки, яка розробляє заходи задля «збереження природою ресурсовідновлювальних і середовищевідтворювальних функцій, генофонду, невідновлювальних ресурсів» $[8$, с. 241]. У географічній освіті найбільшого розвитку природоохоронна тематика отримала у 1960-1970-х рр. паралельно із усвідомленням людством екологічних проблем і загроз. Згодом вона трансформувалася в екологізацію географії, як віддзеркалення нового напрямку досліджень сучасної географії геоекології, що вивчає основні аспекти взаємозв'язку між суспільством і природним середовищем. Як зазначає Н. Винокурова, екологізація шкільної географії здійснювалася відповідно до розвитку екологічних ідей у сучасних географічних дослідженнях: від природоохоронного просвітництва та раціонального використання природних ресурсів до екологізації змісту на основі екологічних проблем, її великим досягненням у цій галузі $€$ розроблення геоекології як галузі наукових знань і відповідного «геоекологічного підходу, який поєднує центризм екологічного підходу до життя у всіх його виявах з унікальними рисами географічного: комплексність, соціальність, просторово-часові характеристики, середовищний підхід, гуманістична спрямованість» [2, с. 5].

В. Кріщунас виокремив в екологізації шкільної географії природоохоронний аспект: «принцип екологізації ... передбачає націлювання географії на виховання природоохоронної свідомості» [6, с. 27]. Підсумовуючи висловлювання дослідників з приводу трактування терміна «екологізація», С. Васильєв і В. Соломін зазначають, що найчастіше вона зводиться або до природоохоронної освіти, або до принципів навчання [1].

Оскільки екологія зародилася як біологічна наука, то в екологічній літературі простежується тенденція до підміни охорони природи охороною біосфери як сфери, у якій виникла, живе і може жити людина. У нашому розумінні в шкільній географії охорона природи тотожна охороні географічної оболонки загалом і географічного середовища зокрема на основі геосистемного підходу. Узагальнимо біологічні і географічні підходи до вивчення природоохоронних питань у шкільних курсах географії та біології (рис. 1).

Загальновизнано, що на відміну від географічного (який відображає рівність елементів геосистем), екологічний підхід є «щентрально-орієнтованим», тобто територія розглядається в аспекті екологічної сприятливості для біоти (природоцентризм) та людини (антропоцентризм). Специфікою геоекологічного підходу є акцент на збереженні природного середовища як ландшафту на засадах коеволюції- спільному і взаємозумовленому процесі взаємодії та розвитку системи суспільства і природи.

Зокрема, у географічних дослідженнях ландшафтно-екологічний підхід розглядається як частковий вияв геоекологічного підходу, за яким пріоритетними функціями узгодженого розвитку будь-якого регіону (за М. Гродзинським) $є$ антропоекологічна (забезпечення та відтворення умов середовища життєдіяльності людини) та природоохоронна (збереження біорізноманіття i забезпечення стійкості та динамічної рівноваги антропогенізованих геосистем). 


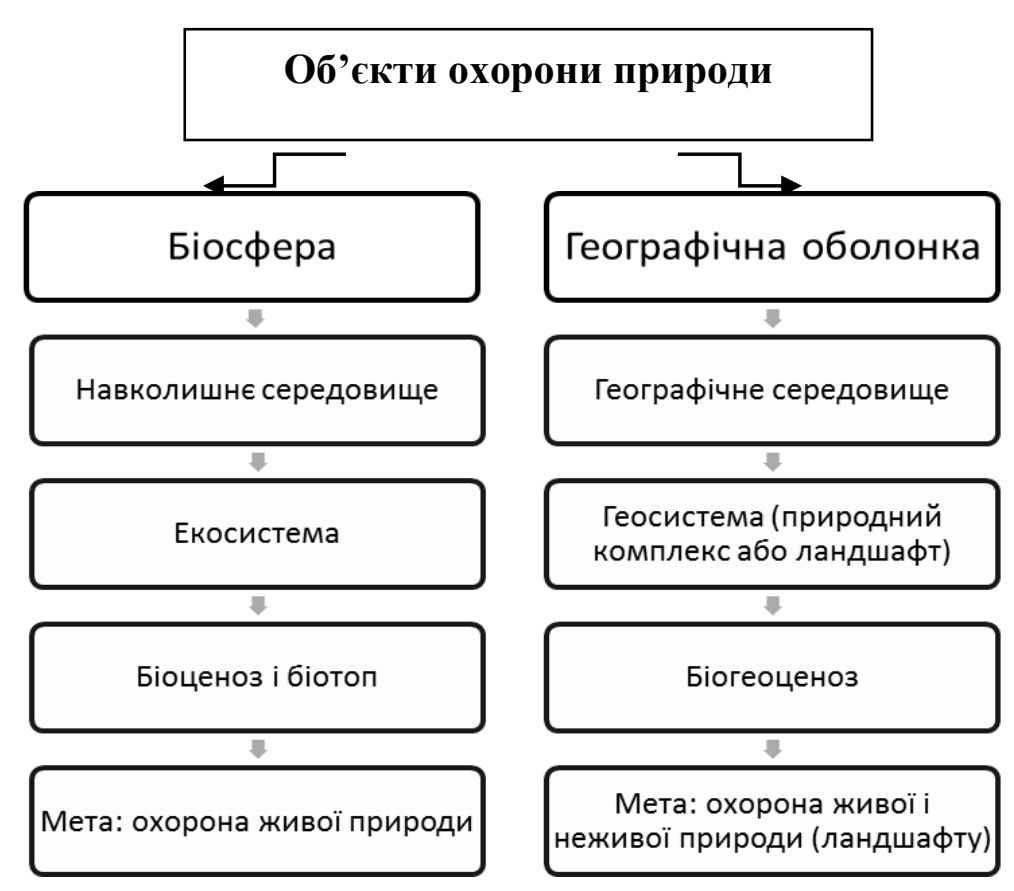

Рис. 1. Біологічний (ліворуч) і географічний (праворуч) підхід до формування змісту природоохоронних знань

У структурі екологічних знань власне охорона природи відноситься до прикладної екології. На думку М. Реймерса, охорона природи, або созологія (від «созо», що означає «врятовую»),- це прикладна екологічна галузь знань про збереження систем життєзабезпечення Землі $[12$, c. 13]. Іншим напрямком прикладної екології $\epsilon$ середовищологія (за М. Реймерсом), або енвайроментологія, 3 яскраво вираженим антропоцентричним підходом. У шкільній географії під охороною природи розуміють

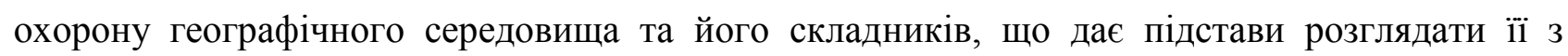
позицій геоекології, що виникла на стику екології, як біологічної науки, і географії. Тому методологічною основою формування природоохоронних знань учнів у сучасних умовах $\epsilon$ геоекологічний підхід. Згідно з ним основними об'єктами охорони визнаються сучасні ландшафти (геосистеми), під якими розуміють керовані або контрольовані людиною територіальні системи, що представляють ділянки ландшафтної сфери 3 характерними для них процесами тепло- і вологообміну, біогеохімічними кругообігами, певними видами господарської діяльності і соціокультурних відносин.

Складність співвідношення екологічної і природоохоронної проблематики в шкільних курсах географії підтверджується різними підходами науковців до визначення їх об'єктнопредметної специфіки. Наприклад, у понятійно-термінологічному словнику «Навчання географії» зазначено: «екологічний - той, що стосується стану охорони, збереження й відтворення складників довкілля; природоохоронний» [10, с. 81]. Тобто маємо ототожнення дефініцій «екологічний» і «природоохоронний». На наш погляд, це можливо у тому випадку, коли дослідники розглядають широке тлумачення охорони природи, включаючи до ії складу раціональне природокористування i забезпечення комфортних умов життя й здоров'я людини, тобто енвайроментальний підхід.

У надрах географічної науки протягом останніх десятиліть відбулася еволюція понять у галузі навколишнього середовища та парадигмальні зрушення в розумінні процесів взаємодії суспільства і природи - від охорони природи до геоекології та 
енвайроментології (рис. 2).

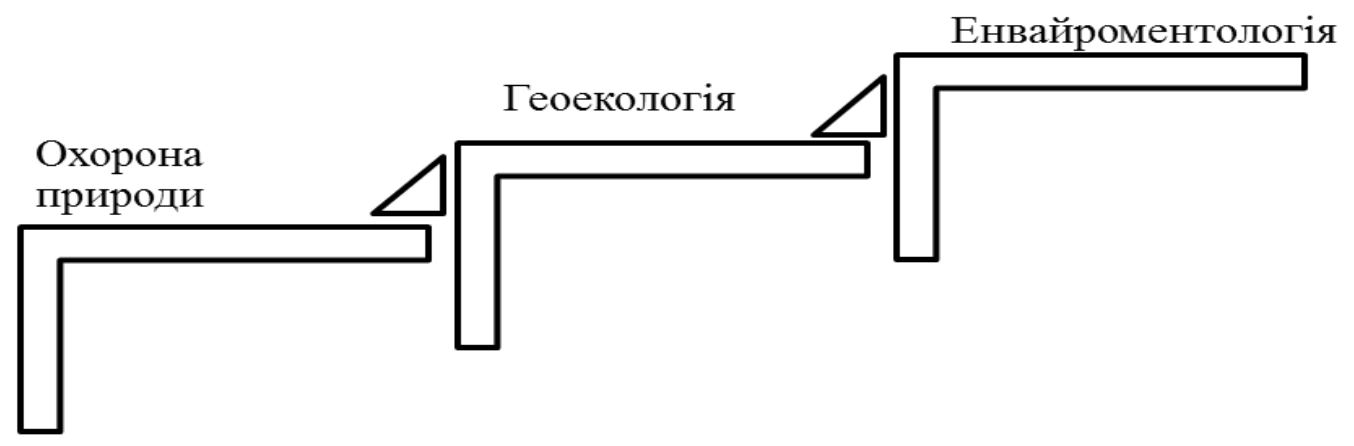

Рис. 2. Парадигмальні зрушення в галузі навколишнього середовища в географічній освіті та науці

Ha VIII з’їзді Українського географічного товариства (Луцьк, 2000) у колективній доповіді «Географічна наука на рубежі століть» разом 3 іншими ставилася проблема необхідності введення до наукової термінології поняття, яке відповідало б змісту науки про навколишнє середовище. Це була своєрідна реакція на розуміння загрози у науці й освіті, викликана можливістю заміщення поняття «навколишне середовище» поняттям «екологія». Таким терміном було запропоновано «інвайрологію» (англ. environment), визначено іiі основні завдання, наголошено, що це потребує подальшого осмислення і певних дій [13, c. 5]. За міжнародними документами, енвайроментальна освіта - це освіта про навколишнє середовище, засобами навколишнього середовища i для навколишнього середовища. Водночас на пострадянському просторі склалася практика ототожнювати екологічну (ecological education) й енвайроментальну освіту (environmental education), наприклад, у дослідженні Г. Каропи (Білорусь) та інших науковців ці три компоненти розглядаються як складники екологічної освіти [4, с. 24-25].

У монографії Л. Нємець звертається увага на термінологічну плутанину в галузі освіти про навколишне середовище, коли все це називають екологічною освітою або (що ще, на їі думку, гірше) природоохоронною освітою. Будучи прихильницею енвайроментальної освіти Л. Нємець уважає за необхідне чітко визначити всі поняття і терміни, спираючись на міжнародні стандарти. Енвайроментальна освіта (за J. Palmer, 1998) - це процес формування ціннісних установок і концепцій задля розвитку умінь і навичок, необхідних для розуміння й оцінки взаємодії між людиною, його культурою і природним оточенням. Вона включає також практику прийняття рішень і розвитку самосвідомості, енвайроментальної етики, типів поведінки і навичок діяльності, що стосуються якості навколишнього середовища [11, c. 271].

У Міжнародній хартії географічної освіти (1992 р.) наводиться визначення географії як науки, що розглядає питання взаємодії людини та довкілля стосовно певної території, тому за підходами науковців англомовного середовища, географічні аспекти охорони природи є просторовою енвайроментальною освітою (Spatial Environmental Education).

Загальновідомо, що наукові знання поділяються на теоретичні та емпіричні, тому ми спробували розробити структуру природоохоронних знань учнів, які вони опановують у процесі навчання географії (рис. 3).

Географічною специфікою природоохоронних знань є їх просторова організація $\mathrm{i}$ локалізація, тому необхідним елементом змісту є включення географічної номенклатури природоохоронної тематики. Наприклад, назв природоохоронних територій, об'єктів 
всесвітньої спадщини ЮНЕСКО, місць екологічних катастроф.

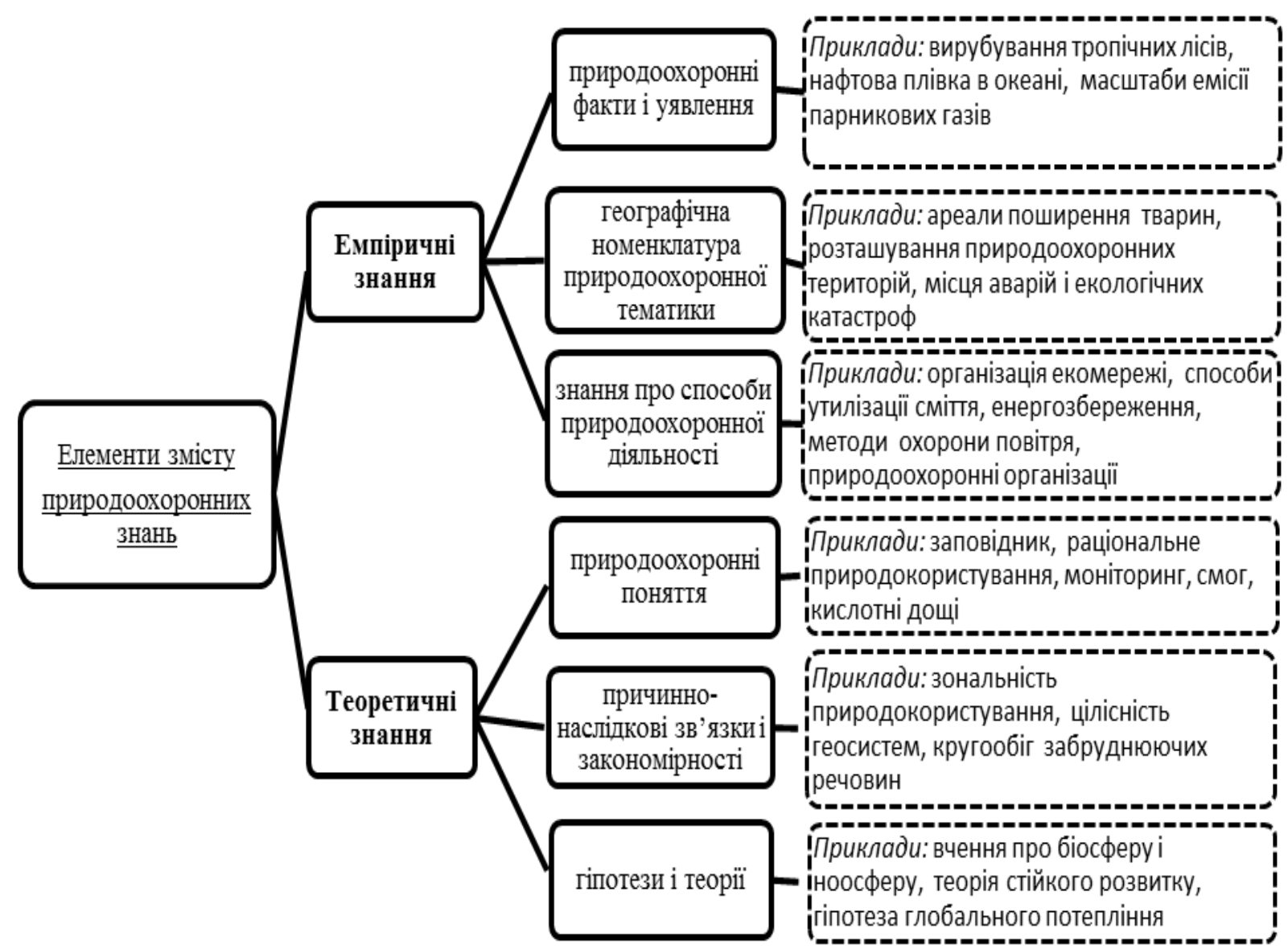

Рис. 3. Елементи змісту природоохоронних знань у процесі навчання географії.

Критеріями відбору природоохоронних фактів $є:$ науковість $i$ достовірність, актуальність $і$ новизна. Наприклад, статистична інформація стосовно обсягів забруднень, зменшення площі лісів, кількості зниклих видів швидко застаріває, проте є необхідним підгрунтям для формування теоретичних знань, тому одним із критеріїв їх відбору $\epsilon$ доцільність $і$ необхідність для формування понять і причинно-наслідкових зв'язків. Обсяг і глибина засвоєння теоретичних природоохоронних знань визначається змістом чинної програми з географії.

Ще однією підставою для структурування природоохоронних знань учнів є напрями охорони природи, які традиційно визначають у шкільній освіті: екологічний, поресурсний, заповідний, економічний i соціально-політичний [3]. Ми спробували проаналізувати представлення сучасних природоохоронних знань у шкільних курсах географії основної школи за цими напрямами і з'ясували, що у курсі географії 6 i 7-го класів домінує екологічний напрям охорони природи, який доповнюється поресурсним напрямом у «Загальній географії» (6 кл) та заповідним - у «Географії материків і океанів» (7 кл). У змісті чинних програм із фізичної географії в основній школі майже не представлені економічний $\mathrm{i}$ соціально-політичний напрямки охорони природи, в той час, коли в умовах ринкової економіки, дотримання принципу «екологічне - економічно» $\epsilon$ одним із провідних у впровадженні природоохоронних заходів, а більшість геоекологічних проблем набули наднаціонального масштабу і їх розв'язання неможливе без міжнародного співробітництва 
на політичному рівні.

Отже, в умовах вульгаризації поняття «екологія», більш адекватним є трансформація природоохоронної освіти у процесі навчання географії не в екологічну, а в енвайроментальну освіту, як освіту в галузі навколишнього середовища, що є більш узгодженим із світовою наукою i практикою, а природоохоронні знання можна розглядати як когнітивноінформаційний компонент енвайроментальної освіти, одним із компонентів якої є освіта «про» навколишнє середовище.

Особливістю формування природоохоронних знань у процесі навчання географії $\epsilon$ комплексний розгляд проблем антропогенного впливу на природу через інтеграцію природничо-наукових i суспільних (соціально-економічних) знань, який досягається застосуванням геоекологічного підходу. Його реалізація забезпечується охопленням у змісті навчальних програм як усіх елементів змісту природоохоронних знань (теоретичних $\mathrm{i}$ емпіричних), так і напрямків охорони природи: екологічного, поресурсного, заповідного, економічного і соціально-політичного. Геоекологічний підхід полягає у вивченні процесів і результатів взаємодії природи, населення і господарства на певній території. Засвоєння основ охорони природи і раціонального природокористування на основі геоекологічного підходу забезпечує вивчення міжпредметних аспектів природничих наук, насамперед географії i біології. Розмежування між ними у сфері формування природоохоронних знань пролягає у фокусі уваги на просторових рівнях (вищих у географії і нижчих у біології) організації геосистем (у географії) і екосистем (у біології), проте вони інтегруються на рівні ландшафту завдяки геоекологічному підходу до їх вивчення.

У сучасній шкільній практиці формування природоохоронних знань в учнів основної школи у процесі навчання географії здійснюється 3 урахуванням дидактичного принципу міжпредметності та геоекологічного підходу до розуміння проблем взаємовідносин людини і природи, проте недостатньо враховується дидактичний принцип наступності знань шкільних курсів природознавства та фізичної географії, тому, на нашу думку, слушним є або включення базового для географії поняття «геосистема» (природний комплекс, ландшафт) до змісту шкільного курсу природознавства, або згадування екосистем, їх особливостей та співвідношення $з$ поняттям природного комплексу у змісті загальної географії. В іншому випадку екологічні знання про цілісність і взаємозв'язки у природі можуть залишитися предметними уламками окремих дисциплін природничого циклу - біології, географії, хімії, фізики.

\section{Література}

1. Васильев С. В. Экологическое обучение и воспитание в системе школьного географического образования / С. В. Васильев, В. П. Соломин. - Санкт-Петербург : Изд-во РГПУ им. А. И. Герцена, 2007. - 215 с. 2. Винокурова Н. Ф. Теория и методика изучения глобальных экологических проблем на основе геоэкологического подхода в курсе школьной географии : автореф. дис. на соискание ученой степени д-ра пед. наук : 13.00.02. «Теория и методика обучения географии»/ Н. Ф. Винокурова. - M., 2000.- 42 с. 3. Воїнственський М. А. Охорона природи : [посіб. для вчителів] / М. А. Воїнственський, С. М. Стойко. - Київ : Радянська школа. 1977. - 144 с. 4. Каропа Г. Н. Экологическое образование школьников: ведущие тенденции и парадигмальные сдвиги. - Минск: НИО, 2000. - 210 с. 5. Копилець С. В. Екологічне виховання шестикласників у процесі вивчення тем «Біосфера» та «Географічна оболонка»/ Свгеній Копилець // Географія та основи економіки в школі. - 2010. - № 3. - С. 34-36. . Крищюнас В. Л. Географическое образование в средней школе. Концепция перестройки содержания / В. Л. Крищюнас // 
География и культура : сб. материалов к IX съезду Географического общества. - Л. : Изд. ГО СССР, 1990. - С. 25-29. 8. Лаптев А. А. Охрана и оптимизация окружающей стреды / А. А. Лаптев, С. И. Приемов, И. Д. Родичкин, Ю. С. Шемшученко; под. ред. А. А. Лаптева. К. : Киев, 1990. - 256 с. 9. Максаковский В. П. Географическая культура : [учеб. пособие для студентов вузов] / Владимир Павлович Максаковский. - Москва : Гуманит. изд. центр «ВЛАДОС», 1998. - 416 с. 10. Навчання географії: Понятійно-термінологічний словник [3 грифом МНОМС України] $\quad$ В. М. Самойленко, Я. Б. Олійник, Л. П. Вішнікіна, І. О. Діброва. - Київ : Ніка-Центр, 2014. - 352 с. 11. Нємець Л. М. Стійкий розвиток: соціально-географічні аспекти (на прикладі України): [монографія] / Л. М.Нємець.Харків : Факт, 2003. - 383 с. 12. Реймерс Н. Ф. Экология: теории, законы, правила, принципы и гипотезы / Н. Ф. Реймерс. - Москва: Россия молодая, 1994. - 367 с. 13. Руденко Л. Г. Сучасні парадигми географії / Л. Г. Руденко // Географічна наука і освіта в Україні: [зб. наук. праць] / Гол. ред. Я. Б. Олійник. - Київ : Фітосоціоцентр, 2000. - С. 3-5. 14. Черваньов I. Г. Інвайроментологія - наука про «оселю людини» та іiі поступ / I. Г. Черваньов // Український географічний журнал. - 2004. - № 1. - С. 57-64. 